\title{
The Daily Use of the Arts in Early Years in Queensland, Australia
}

\author{
Susanne Garvis, Griffith University, Australia
}

Abstract: The arts are an important learning area for young children. The arts provide a medium for children to explore, make sense of and communicate about the world around them. As yet, few studies have explored current arts practice in Australian early years classrooms and the development of the associated domain-intrinsic knowledge with each of the arts. This paper explores the daily routines of arts practices in the first year of formal schooling in Queensland, Australia through interviews with six early childhood teachers. The focus is to determine if the arts are a supplemental tool or a developmental tool. Findings provide information about the way arts education is currently being embedded into early childhood programs, and the types of domain-intrinsic knowledge that is being taught to children aged three and a half years. Findings highlight that the early childhood teachers did not feel confident teaching the arts as a developmental area.

Keywords: Early Childhood, Domain Knowledge, Creativiy

\section{Introduction}

$\mathrm{T}$ The arts are a key learning area in early childhood education. In 2009, the document Belonging, Being and Becoming- The Early Years Learning Framework for Australia (Australian Government Department of Education, Employment and Workplace Relations for the Council of Australian Governments, 2009) was released for all children aged birth to five years. The Early Years Learning Framework (EYLF) is part of the Council of Australian Government's (COAG) reform agenda for early childhood education and care and is a key component of the Australian Government's National Quality Framework. It underpins universal access to early childhood education and will be incorporated in the National Quality Standard. Universal access means all children in the year before formal schooling should have access to a quality early childhood program with a registered teacher.

The Early Years Learning Framework describes the principles, practice and outcomes essential to support and enhance young children's learning from birth to five years of age. The Framework has a strong emphasis on play-based learning as the best vehicle for children's learning and development. The Framework also recognizes the importance of communication and language and social and emotional development.

The document notes the arts as an important area for children, raising awareness of the arts in education nationally for the early years.

The arts are also a key learning area in the Phase Two National Curriculum for Australia. The Curriculum is intended to be rolled out across Australia over the next few years. The National Curriculum is intended for children in all years of formal schooling.

Arts education (dance, drama, music, visual arts and media) is an important component of an early childhood education. The arts are the first tool that children use to make meaning of the world around them. It is one of the first communication tools that young children engage with. Some teachers however may not feel confident or capable of teaching the arts to young children. Subsequently some teachers may use the arts more as a supplemental tool in the classroom to aid other developmental areas such as literacy and numeracy. The arts are positioned as a learning tool, not as a developmental area.

In Queensland, the early years of formal schooling are known as preparatory year, year one, year two and year three. This study explores the ways the arts are used in six early years

The International Journal of Arts Education

Volume 7, 2013, www.artsinsociety.com, ISSN 2326-9944

(C) Common Ground, Susanne Garvis, All Rights Reserved

Permissions: cg-support@commongroundpublishing.com 
generalist preparatory classrooms (children aged five years) in Queensland, Australia. The focus is to determine if the arts are a supplemental tool or a developmental tool. Interviews were conducted with six early years teachers (two teachers were based in state schools and two teachers were based in private schools). Data was analysed using content analysis. Themes emerged suggesting the arts were used as a tool to teach other learning areas that were considered more important in the future National Curriculum (namely literacy and numeracy). The arts were positioned as a suitable supplemental tool to teach the developmental areas. The early years generalist teachers in this study did not feel confident teaching the arts as a developmental area.

\section{Literature}

The arts are an important learning area for young children and included in many education programs. Early interactive dialogue vocalization between infant and caregiver is considered important for supporting communicative and caring acts (Trevarthen and Malloch 2000). Researchers argue that the blend of music and language elements supports early acquistion of speech and music (Papousek 1996). The phenomenon is considered the foundation to infant identity (Trevarthen 2002) and is implicated in the development of the arts in human thought and activity (Dissanayake, 2000). Barrett $(2006,207)$ further argues that "children's creative thought and activity arise from early adult-infant interactions where the foundations for language, music and emotional, social and cultural development are laid down".

The role of the early years teacher is to enhance the development of domain-intrinsic knowledge in young children (Pramling Samuelsson et al. 2009). Teachers often introduce such tools through the terminology in which they phrase their questions to children (Pramling and Wallerstedt 2009). According to Pramling Samuelsson et al. $(2009,133)$ "these distinctions and concepts become the tools through which children develop their aesthetic perception". The role of the early years teacher should therefore focus on the arts as a developmental area, not a supplemental tool.

Previous studies suggest Australian early years teachers have lower self-efficacy towards the arts (dance drama, music, media and visual arts) (Alter et al. 2009; Davis 2008; Garvis and Pendergast 2011; Garvis, Pendergast and Twigg 2011). In both studies, early childhood teachers had lower confidence and perceived capability for teaching the arts subjects compared to literacy and numeracy. Similar findings have been made with generalist beginning middle years teachers in Australia (Garvis 2010). Garvis (2010) found that lower confidence in middle years teachers was attributed to a lack of prior experience, little opportunity to engage with the arts in teacher education and little valuing of the arts in the school community.

In Queensland where this study was conducted, there has been a strong focus on literacy and numeracy following the introduction of the National Assessment Plan for Literacy and Numeracy in 2008 and A shared challenge: Improving Literacy, Numeracy and Science Learning in Queensland Primary Schools (Masters 2009) on ways to improve literacy and numeracy in Queensland schools. In the Queensland Kindergarten Learning Guideline (Queensland Studies Authority 2010) for children aged three and a half years attending kindergartens, literacy and numeracy are the only subject areas given special mention for children's learning. Other subjects are positioned as a means for increasing children's awareness about the world but also a form of improving literacy and numeracy.

This study focuses on the classroom practices of six early years teachers who currently teach in preparatory classrooms in Queensland, Australia. The preparatory year is the first year of formal schooling (children aged five) in the Queensland education system. Interviews were conducted with teachers to discuss if the arts were used as a developmental tool or a supplemental tool in the classroom. 


\section{Method}

Early years teachers in this study were recruited via convenient sampling after ethical clearance was gained for this study. Four early years teachers worked in private schools and two early years teachers worked in state schools.

A thirty minute semi-structured interview was conducted with each of the early years teachers after school. Early years teachers had received the interview schedule one week before to ensure they knew the nature of questions. The interview was digitally recorded and then transcribed. The transcription was sent to the early years teacher for verification before it was analysed.

Content analysis was used for this study. An adapted version of Cavana, Delahaye and Sekaran's (2003) fifteen stages of content analysis (based within the constant comparative method) was used as a guide to identify key themes and meanings in the data. This process allowed newly identified themes to be compared with previously identified themes. Themes were located with frequency counts. Coding for manifest content (Wallen and Fraenkel 2001) was used, which means that what was directly written in the online blog, as opposed to latent content which is implied, was used for the content analysis. Three themes emerged; (1) the arts as a supplemental tool to help implementation of the National Curriculum, (2) limited confidence and perceived capability, and (3) professional development is needed in arts education.

\section{Findings}

\section{The Arts as a Supplemental Tool to Help Implementation of the National Curriculum}

All of the six early childhood teachers suggested they used the arts as a supplemental tool to help implement the National Curriculum (namely literacy and numeracy). All six teachers said they used the arts as an integrative tool to help students remember concepts, encourage relaxation and provide activities for topics. Comments included:

I'd say I've used the arts as an integration tool. So far this year I've probably done about three activities where the arts were the tool for other areas (Teacher 2).

I'd say the role of arts in education would be to coincide with your literacy programs so they can be either integrated or not, but I think they're a way of children being able to showcase their various talents (Teacher 4).

I find it an avenue for engaging the students in learning. So, I use a lot of songs with the kids to remember things or to, even just as like a relaxation thing, or to like learn a topic or something like that (Teacher 6).

Five early childhood teachers also commented on specialist teachers in their school who taught the developments needs for music. The early childhood teachers also suggested that the majority of skills and knowledge specific to the arts was available to children during extra curricular activities (such as private music lessons) that were paid for by parents:

The arts are really an extra curricular activity for children. They learn from the specialists outside of school hours, so we do have a very extra-curricular heavy curriculum. I use the arts as a supplemental tool to help teach other concepts. The specialist teachers take care of the developmental stuff (Teacher 3).

In the two private schools there were specialists for drama, visual arts and music. Children had thirty minutes of specialist training every week. Both private school teachers wondered how 


\section{THE INTERNATIONAL JOURNAL OF ARTS EDUCATION}

the arts were taught in schools without specialist teachers. They realized that in some schools in Queensland, children did not have access to arts specialists. One teacher questioned:

I know some schools don't have specialist teachers. I wonder how the arts are taught? (Teacher 1).

\section{Limited Confidence and Perceived Capability}

All of the early childhood teachers suggested they had limited confidence and perceived capability to teach the domain specific knowledge and skills associated with each of the arts domains. The early childhood teachers reflected on the limited teacher education in the arts compared to other subject areas. The early childhood teachers suggested that their lack of confidence and perceived capability may have resulted from limited exposure in teacher education. Comments included:

We had one subject which was the arts and it was basically a half an hour a week tutorial style of thing and we went in and did dramatic arts there and we had a workshop over the holidays, like I think it was the Easter holidays, which was the dramatic arts workshop as well, so there wasn't much, in fact there wasn't anything on the visual arts in my teacher training (Teacher 1).

I feel most universities currently are more interested in the bums on seats then what's actually being taught in their education for teachers. You know when you have a lecturer that gets up and says to you in that very first lecture I am a failed teacher, you think well fair enough, but then aren't you teaching us now, so (Teacher 5).

Four early childhood teachers commented that their teacher education did not feature media education. For example, one teacher commented:

I don't have the greatest grip on what media is so and there was just nothing said about it. As I said the only education that we got at the universities about art was this is how you conduct a dance lesson and this is how you could conduct a drama lesson. Art is so much more than that (Teacher 2).

\section{Professional Development Is Needed in Arts Education}

All of the six early childhood teachers suggested professional development would help their professional learning about the arts. The teachers however also revealed the lack of professional development activities and resources that were available to them. The early childhood teachers suggested that while there were numerous professional development events for literacy and numeracy, they had seen limited opportunities for the arts that they considered more important for their own current needs. While the teacher felt confident to teach literacy and numeracy, they did not feel confident to teach the arts. Comments included:

What would help me? Probably some professional development where I can see some more examples, some more practical examples and that sort of thing. Yeah I think that would probably help me the most and maybe some more resources in our library because I've sort of exhausted them (Teacher 6).

Professional development for literacy and numeracy are everywhere but I haven't seen anything for the arts. I would really like to have professional learning in the arts to help my confidence (Teacher 3). 
It is sad there is not professional development in the arts, because like I said it is such a fantastic way to get the kids motivated (Beginning Teacher 1).

Overall, the early childhood teachers in the study suggested professional learning would help improve the current problems of teaching arts education as a developmental tool in their early years classrooms. It appears that until professional learning is able to take place, teachers will continue to have low confidence and perceived competence towards teaching the arts with the arts positioned as a supplemental tool to help teach other subject areas.

\section{Discussion and Conclusion}

In this study, early childhood teachers in preparatory classrooms used the arts as a supplemental tool to teach other subject areas. This appeared to be the result of limited understanding about domain-intrinsic knowledge about each of the arts forms and confidence to engage with certain arts forms (such as dancing) in front of young children. The six teachers in this study had limited exposure to arts education in teacher training (the most was one semester for all arts forms) to develop suitable knowledge about the arts and how to teach each of the arts forms.

In this study, while the teachers realized the importance of the arts as a developmental area, they also realized they could not fulfill this expectation and hoped that children would develop skills in the arts from their thirty minute music lesson a week with a specialized music teacher. As a backup, the teachers decided to use the arts the best way they knew how by using it as a supplemental tool for other areas, especially literacy and numeracy. The teachers considered it better for the students to engage in some arts activity, even if the focus was not a developmental aspect linked to the arts. It would be interesting to explore if such an opinion is shared by other teachers in the collective school culture where the early childhood teachers works. If similar views are shared, it raises questions of what is the perceived role of arts education in schools for children. Is arts education, even though it is a subject listed in the National Curriculum for Australia, still positioned as a 'fun' and 'non-academic' subject that is conducted when there is extra time?

The role of arts education in the early years of schooling appears to hold many viewpoints. It would be worthwhile for early childhood teachers to engage in professional development to help explore and challenge these beliefs. Such professional development would need to be sustained over a period of time and also include developing confidence and understanding about each of the arts domains and how to teach each of the arts forms. Such professional development would start to build the foundation for arts education to be positioned as a developmental area, not just a supplemental area for other key learning areas. As the arts appears in the National Curriculum Framework for Australia, it would be considered worthwhile that teachers have appropriate skills and knowledge in teaching arts education.

Arts education is an important developmental area for young children. In this study, the early childhood teachers positioned the arts as more of a supplemental tool than a developmental tool. If children are to be supported in developing their own arts knowledge and skills, they require skilled teachers who are able to support their development. Greater opportunities for access to professional learning and development is needed within Queensland, Australia to help support early childhood teachers in understanding and meeting the needs of young children. It is only when young children have such support with their development that they can reach their true potential. 


\section{REFERENCES}

Alter, F., T.Hays, and R.O'Hara. 2009. “Creative arts teaching and practice: Critical reflections of primary school teachers in Australia." International Journal of Education \& the Arts 10 (9): 1-21. IJEA. http://www.ijea.org/v10n9/ (accessed January 1, 2012).

Australian Government Department of Education, Employment and Workplace Relations for the Council of Australian Governments. 2009. Belonging, Being and Becoming: The Early Years Learning Framework for Australia. Canberra: Council of Australian Governments.

Barrett, M.S. 2006. "Inventing songs, inventing worlds: the 'genesis' of creative thought and activity in young children's lives." International Journal of Early Years Education 14 (3): 201-220. Taylor and Francis Online http://www.tandfonline.com/doi/abs/ 10.1080/09669760600879920 (accessed December 24, 2011).

Cavana, R.Y., B.L. Delahaye, and U. Sekaran. 2001. Applied business research: Qualitative and quantitative methods. Brisbane, Queensland: John Wiley and Sons.

Davis, D. 2008. First we see: The national review of visual education. Canberra: Australian Government.

Dissanayake, E. 2000. Art and Intimacy: How the Arts Began. Seattle: University of Washington Press.

Garvis, S. 2010. "An investigation of beginning teacher self-efficacy for the arts in the middle years of schooling (years 4-9)." PhD Thesis. University of Queensland.

Garvis, S. 2012. in press. "What is going on in early years music planning?: A study of early years teachers' weekly plans." Australasian Journal of Early Childhood.

Garvis, S., and D. Pendergast. 2010. "Supporting novice teachers of the arts." International Journal of Education \& the Arts 11(8):1-22. IJEA. http://www.ijea.org/v11n8/ (accessed March 16, 2011).

Garvis, S., and D. Pendergast. 2011. "An investigation of early childhood teacher self-efficacy beliefs in the teaching of arts education." International Journal of Education \& the Arts 12 (9):1-22. IJEA. http://www.ijea.org/v12n9/ (accessed September 16, 2011).

Garvis, S., D. Twigg, and D. Pendergast. 2011. "Breaking the negative cycle: The formation of self-efficacy beliefs in the arts." A focus on professional experience in pre-service teacher education. Australasian Journal of Early Childhood, 36 (2): 36-41.

Masters, G. 2009. A shared challenge: Improving Literacy, Numeracy and Science Learning in Queensland Primary Schools. Brisbane, Queensland: Queensland Government.

Papousek, M. 1996. "Intuitive parenting: a hidden source of musical stimulation in infancy." In Musical Beginnings, ed I. Deliege and J. Sloboda, 88-112. Oxford: Oxford University Press.

Pramling, N., and C. Wallerstedt. 2009. "Masking musical sense: The multimodal nature of clarifying musical listening." Music Education Research 11 (2): 135-151.Taylor and Francis Online. http://www.tandfonline.com/doi/abs/10.1080/14613800902924433 (accessed on September 25, 2011).

Pramling Samuelsson, I., M.Aspland Carlsson, B. Olsson, N. Pramling, and C, Wallerstedt. 2009. "The art of teaching children the arts: music, dance and poetry with children aged 2-8 years old." International Journal of Early Years Education 17 (2): 119-135. Taylor and Francis Online. http://www.tandfonline.com/doi/abs/10.1080/09669760902982323 (accessed September 25, 2011).

Queensland Studies Authority. 2010. Queensland Kindergarten Learning Guideline. Brisbane: Queensland Studies Authority.

Trevarthen, C., and S. Malloch. 2000. "The dance of well-being: defining the musical therapeutic effect." The Nordic Journal of Music Therapy 9 (2): 3-17. 
Wallen, N., and J. Fraenke. 2001. Educational research: A guide to the process ( ${ }^{\text {nd }}$ Ed.). Mahwah, New Jersey: Lawrence Erlbaum.

\section{ABOUT THE AUTHOR}

Dr. Susanne Garvis: Susanne Garvis is an early childhood lecturer in the School of Education and Professional Studies. Her research areas explore arts education with children aged birth to five years. 
